\title{
BETWEEN INSTITUTIONAL ANTISEMITISM AND AUTHORITARIANISM IN THE Territory OF THE ForMER GALICIA, 1935-1939: DisCUSSION OF THE Problem
}

\author{
Tony Kahane and Andrew Zalewski \\ (Gesher Galicia, London, UK and Philadelphia, USA) \\ e-mail: tkahane@geshergalicia.org, andrew.zalewski@geshergalicia.org
}

Keywords: Jews, antisemitism, 1935-1939

\begin{abstract}
In the period 1935-1939, following the death of head of state Marshal Piłsudski, the Polish national government adopted a more authoritarian and nationalist stance. Piłsudski had been considered by some Polish Jews as a protector of national and religious minorities. After his death in May 1935, institutional antisemitism experienced a dramatic increase.

In the public sphere, certain newspapers regularly featured antisemitic "news reports," opinion pieces and cartoons of an extreme nature. The newspaper $A B C$, for instance, advocated boycotts of Jewish businesses and shops, listing them by name, and encouraged Jewish emigration.

In universities, the increasing discrimination against Jews has been well documented. Most Polish universities instituted restrictions on the number of Jewish students they would admit, or else barred them altogether. The education ministry willingly turned a blind eye to the admission policies of the university authorities. At the beginning of the academic year 1938-1939, for example, only three students in the first year of medical studies in Lwów (less than $1 \%$ of the new intake) were Jews, and none in Kraków.

After discussing antisemitism in newspapers and universities in the late 1930s, this article will examine documents held in the State Archive of Ivano-Frankivsk Oblast (DAIFO) concerning relations between the Jewish communities in the Stanisławów region, and the district, provincial and national authorities, including the national Ministry for Religious Denominations and Public Enlightenment. Much of this documentation concerns the town of Dolina. With the backing of the district authorities, an attempt was made to install as assistant rabbi in the town a certain Ksyel Juda Halberstam. This move was strongly opposed by many members of the Dolina Jewish community, as well as by its senior rabbi. The correspondence sheds light on the protracted struggle between the different parties until the assistant rabbi was finally installed in late 1938 .

These files on the Dolina episode highlight the desire on the part of the authorities to control the rabbis, and through them the members of their communities. Information was systematically gathered on all the rabbis in the province, with particular emphasis on their moral behaviour, their perceived loyalty to the state, and their fluency in the Polish language. These actions, in turn, reflect an underlying suspicion over the extent of the rabbis' "Polishness" and a fear, in an era of growing nationalism, of "antinational" behaviour. Such suspicions of loyalty were particularly marked where rabbis were thought to have Zionist links.
\end{abstract}




\section{Background}

The period 1935-1939 was one of increasing nationalism and authoritarianism in much of Europe, following the coming to power of the Nazis in Germany in January 1933. The year 1938, in Poland and elsewhere, was a critical turning point in the process. Up to then, many people, including in Poland, had sought to deny the threat from Nazi Germany. On 12 March, Germany annexed Austria, with its already strongly authoritarian and semi-fascistic regime. Between 1 and 10 October, following the Munich Conference between Adolf Hitler and the British Prime Minister Neville Chamberlain, Germany annexed the Sudetenland, the border territories of Czechoslovakia. On 28 and 29 October, Germany expelled some 18,000 Polish Jews, many of them who had come from Galicia a generation or two earlier. Twelve days later, the infamous Kristallnacht took place throughout Germany, including Austria. In Italy, the first antisemitic racial laws were promulgated by the fascist regime on 18 November.

In Poland, we consider the period following the death in May 1935 of Józef Piłsudski. Piłsudski, a sort of benevolent-authoritarian figure, had been considered, at least by some Polish Jews, as a protector of national and religious minorities. That was to change over the following four-and-a-half years.

\section{Newspapers}

In the public non-governmental sphere in Poland in the later 1930s, certain newspapers regularly featured antisemitic "news reports," with opinion pieces and cartoons of an extreme and grotesque nature, comparable to the more widely known antisemitism of Nazi German newspapers such as Der Stürmer. Newspapers in Poland, including $A B C$, called for boycotts of Jewish businesses and shops, listing them by name, and encouraged Jewish emigration. ${ }^{1}$

\section{Universities}

In public institutions, the increasing discrimination against Jews has been well documented. Most Polish universities instituted restrictions on the number of Jewish students they would admit, or else barred them altogether, in stark contrast to the position maintained in the early 1930s. The education ministry, if not actively implicit in introducing a strict numerus clausus in higher education, willingly turned a blind eye to the practices

\footnotetext{
${ }^{1}$ ABC: Nowiny Codzienne, 6 February 1938, no. 39A: 1, 3. Two articles calling for governmental actions against Jewish shops in Warsaw. ABC: Nowiny Codzienne, 29 June 1938, no. 190: 1. Under the frontpage headline, "Liquidate Jews!" there is a report on the growing public support to force Jewish emigration from Poland. Ibid., 30 June 1938, no. 191A: 4. Several columns are given to targeting the presence of Jewish businesses in eastern Poland.
} 
of the university authorities, allowing them to follow their own admission policies. ${ }^{2}$ In the academic year 1922-1923, for example, 45\% of medical students in Lwów were Jewish, with $26 \%$ at the Jagiellonian University in Kraków. ${ }^{3}$ By $1937-1938$, the figure in Lwów had fallen to $12 \%$, with a similar proportion in Kraków. ${ }^{4}$ The Faculty of Medicine of the Jagiellonian University then moved in 1938 to entirely ban new Jewish students, taking effect in the academic year 1938-1939. ${ }^{5}$ At the beginning of the academic year 1938-1939, only three students in the first year of medical studies in Lwów were Jews, ${ }^{6}$ and none in Kraków. The 1930s, in fact, saw increased migration of Jews to study medicine in Prague, where Jewish students continued to graduate until June 1939.7 Many of these students in Prague chose not to return to Poland because of antisemitism.

Another manifestation of institutional antisemitism in education was the segregation of Jewish students in lecture rooms (on "ghetto benches"), which was promoted by the nationalistic student organization, All-Polish Youth, and ultimately approved by the senates of several universities in Poland. The Jagiellonian University was the first university in Poland forced to suspend classes, in October 1931, as a result of anti-Jewish violence. ${ }^{8}$

Violence and unrest were particularly strong at Lwów University and Lwów Polytechnic. The students from the All-Polish Youth organization declared certain days "Jewfree" and in November-December 1937 stopped Jews from entering. ${ }^{9}$ Jewish students went on a hunger strike and professors accused of Jewish sympathies were pelted with eggs or attacked in pamphlets as defenders of "Judeo-Communism" (żydokomuna). For safety reasons, Jewish students started to attend lectures in groups, and were given special days to sit their examinations.

In 1938, Karol Zellermayer, a pharmacy student, was stabbed on the campus of Lwów University and died. The same year, Samuel Proweller, a polytechnic student, was murdered, and in May 1939, Markus Landesberg was viciously beaten and later died. ${ }^{10}$

${ }^{2}$ Mick 2016: 244.

${ }^{3}$ For the information on Lwów University Kronika Uniwersytetu Jana Kazimierza 1926: 37. For the information on the Jagiellonian University, see Kulczykowski 2004: 67.

${ }^{4}$ Rocznik Polityczny i Gospodarczy 1939: 513. For detailed information on the percentage of Jewish students at Polish universities in the academic year 1937/1938.

5 Academia Militans 2015: 191. A complete halt on the enrollment of Jewish students, the so-called numerus nullus, was instituted at Poznań University in 1936/1937, followed by the Faculty of Medicine at the Jagiellonian University.

${ }^{6}$ Zalewski 2019: 5. Based on the research of the records of Lwów University held at the State Archive of Lviv Oblast, DALO, Fond 26, desc. 10, case 1700.

7 Zalewski 2019: 6-7. Based on the research of the records from the Archives of Charles University, Prague: German University (Matricula doctorum and Doktoren Matrik); and Charles (Czech) University (Matrika doctoru), Fond 187, inventories 1-6, and Fond 180, inventories 1-10, respectively.

${ }^{8}$ Academia Militans 2015: 189-190.

9 ABC: Nowiny Codzienne, 1 February 1938, no. 34A: 6. At Poznań University, a students' mutual aid organization (Bratniak) passed a statutory rule that no student of "the Mosaic religion or following the Mosaic religion" could join. When there was some doubt, a prospective candidate had to prove the lack of a Jewish ancestor for three generations back.

10 Mick 2016: 245. 


\section{State activities}

We now turn to the actions of the state, at the national and local levels, regarding Polish Jews and in particular rabbis. A noteworthy case study is documented in two large files in the State Archive of Ivano-Frankivsk Oblast (DAIFO) in Ukraine. ${ }^{11}$ They contain correspondence involving the provincial administrative office (the województwo) and provincial governor (the wojewoda); the local district offices (starostwo) in towns throughout the province and their administrative heads (the starosta); the Ministry for Religious Denominations and Public Enlightenment; and rabbis and members of the local Jewish communities.

The first file, from 1936-1937, deals almost exclusively with Jewish matters, and largely with rabbis. The second, from 1938, is concerned only with the rabbis. Many of the documents from the state institutions draw their legitimacy from an ordinance of 1930, which would appear to have been applied increasingly strictly and according to the letter. ${ }^{12}$ This ordinance, issued by the Ministry of Religious Denominations and Public Enlightenment, governed matters such as the elections of rabbis, and gave power to the local starosta in several areas with regard to the Jewish community and its rabbis. The starosta was obliged to pass on relevant information on rabbis to the wojewoda, who was free to inform the ministry. Considerable emphasis was placed on a particular quality that rabbis were expected to possess: a high level of proficiency in the Polish language.

Candidates for rabbi also needed to prove their religious knowledge on the basis of guidelines approved by the official Board of Rabbis - a board which was itself appointed by the ministry. Instructions for the organization of elections of rabbis originated from the ministry. The ministry also sought information on matters such as the income earned by Jewish communities from ritual slaughtering.

Much material in these files relates to a long-running episode in the town of Dolina, near Bolechów and Kałusz. This began on 11 June 1936, when 91 members of the Jewish community of Dolina wrote to the wojewoda of Stanisławów, complaining about an election that had taken place in the town of an assistant rabbi (podrabin). ${ }^{13}$ This person was Ksyel Juda Halberstam, born in Rudnik on 14 May 1904 and aged 32. The writers complained that the community did not need an assistant rabbi, that in fact there was already a deputy rabbi in Dolina (Szymon Hollech), and that, in any case, they could not afford one. They added that the election itself was invalid, with people on the street randomly having been asked to vote. It was also claimed that Ksyel Juda Halberstam had falsified his school records in his application to be assistant rabbi.

${ }^{11}$ DAIFO, Fond 2, desc. 1, case 2081, Correspondence on Religious Affairs, 1936-1937; and Fond 2, desc. 1, case 2086, Correspondence on Religious Affairs, 1938. The first of these files is largely on Jewish religious matters, much of it on rabbis, though it also includes one matter to do with a Greek Catholic church in Okna (Vikno), near Horodenka. The second file is exclusively on Jewish matters.

12 Ordinance of the Minister of Religious Denominations and Public Enlightenment of 24 October 1930, on the rules for elections of rabbis and assistant rabbis in Jewish communities in the territory of the Republic of Poland, with the exception of the Silesian voivodeship (Rozporządzenie Ministra Wyznań Religijnych i Oświecenia Publicznego z dnia 24 października 1930 r. w sprawie regulaminu wyborczego dla wyborów rabinów i podrabinów w gminach wyznaniowych żydowskich na obszarze Rzeczypospolitej z wyjątkiem województwa śląskiego).

${ }_{13}$ DAIFO, Fond 2, desc. 1, case 2081: 64-67. 
After the initial letter from the dissident Dolina community members, the district office wrote to the wojewoda refuting their claims, maintaining that the election was valid, and that its terms had been approved by the leaders of the Jewish Council of Dolina, under an agreement in which the starosta had also approved the community's budget. The district office also wrote that Ksyel Juda Halberstam had been serving unofficially as assistant rabbi for some time. They added that while it did appear that Halberstam had falsified his school certificate, he nonetheless enjoyed respect from the community, spoke Polish and was loyal to the state, and that as a result, the district office was willing to put aside the matter of the falsification. In exchange for the falsification matter being dropped, Halberstam would, however, have to take the examination for proficiency in Polish. ${ }^{14}$

Others joined the controversy. The main rabbi in Dolina was Ozjasz Halberstam. His relationship to Ksyel Juda is unknown, although the Halberstam family was a wellknown rabbinic clan in Galicia. Ozjasz was born in 1876, and had been in the position since 1928. In January 1937 (more than six months after the controversy started), he wrote directly to the ministry in Warsaw, quoting sections of the ordinance of 1930 governing the election of rabbis, and adding his voice to the objections against Ksyel's appointment. ${ }^{15}$ Instead of acknowledging his letter, however, the ministry sent a sharp note to the provincial office, asking them to admonish Ozjasz for having written directly to the ministry, as the regulations stipulated that he should have addressed complaints to the starosta in the first place, who would then forward them to the wojewoda ${ }^{16}$ The tone of the ministry's letter is much stronger - to the point of being almost offensive - than the relatively neutral tone of the correspondence from the district and provincial offices.

The opponents of Ksyel Juda again took up the matter of his allegedly having falsified his school records, and the argument continued for much of the rest of 1937. A criminal investigation was launched and Ksyel was charged. On 24 September 1937, the regional court in Stryj finally held a trial over the charge, at which Ksyel was acquitted). ${ }^{17}$ The prosecutor, however, appealed against acquittal and on 20 December 1937 the case went to a higher court in Lwów, which upheld the original decision from Stryj. At that point, Ksyel Halberstam was officially clear of the charge.

Earlier in the year, Ksyel had indeed taken his examination in Polish. He had said he wanted to take the exam, for which he had paid the fee, and he went to great lengths to satisfy the authorities and prove his proficiency in Polish. A report from the examination board of 16 June 1937 states that in the exam Ksyel had been asked to read a newspaper story, "Help for Bilbao," about the civil war in Spain, and a text about the political

${ }_{14}$ Ibid.: 67, Letter of 22 October 1936, in which the starosta of Dolina dismissed the allegations of Ksyel's opponents and asked the wojewoda of Stanisławów not to punish Ksyel for falsifying his certificate, but instead have him take the examination.

${ }^{15}$ DAIFO, Fond 2, desc. 1, case 2081: 59 Letter dated 22 January 1937, received by the Ministry on 25 January 1937.

16 Ibid:: 58, Letter from the Ministry of Religious Denominations and Public Enlightenment, dated 29 January 1937.

17 Ibid.: 37, Letter of 6 November 1937, in which the starosta of Dolina reports to the voivodeship office in Stanistawów that Ksyel had been acquitted at the hearing held on 24 September 1937 at the Regional Court in Stryj. 
system of the Second Polish Republic. ${ }^{18}$ His written task was to produce a paper on the topic of "The position of rabbis in Jewish communities; what is the character of Jewish communities and their leaders?" Ksyel produced a single handwritten page as his answer. We might assume that the examination board would, as a rule, have required a longer paper, and that the minimum standards had been lowered in his case. The result of his exam was given as "satisfactory," the lowest passing grade.

As already noted, the dispute that started in mid-1936 continued throughout 1937 and 1938. Ksyel's position as podrabin was finally confirmed officially by the ministry on 21 September 1938 (see Figure 1). ${ }^{19}$

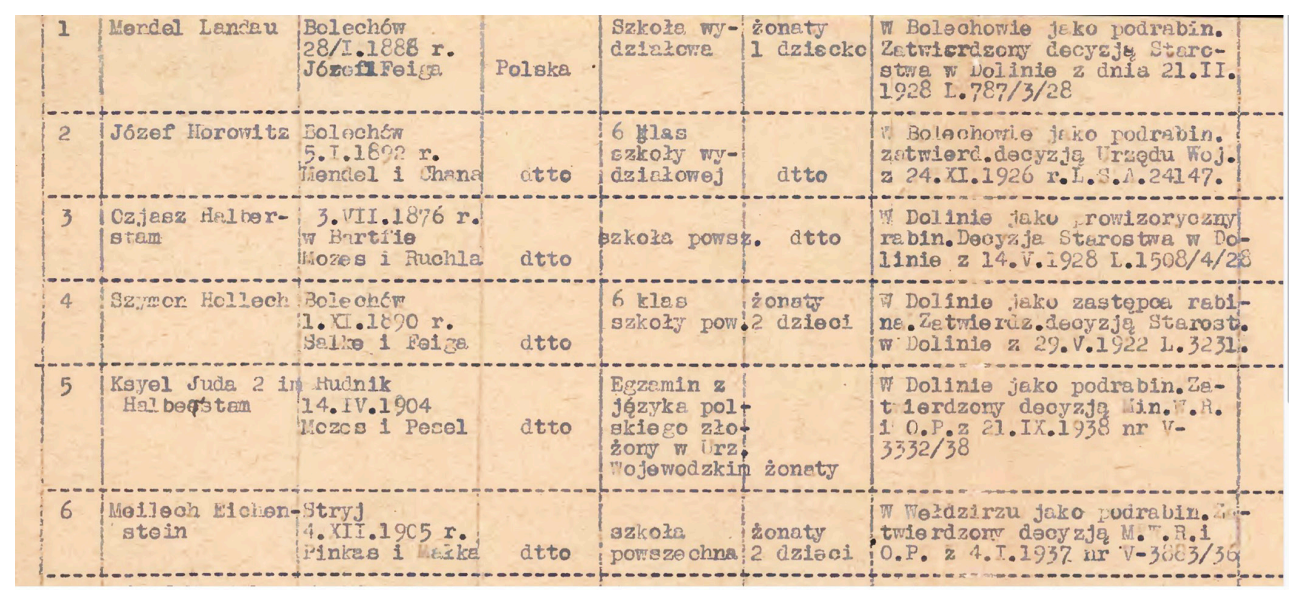

Figure 1. Part of table listing 61 rabbis in Stanisławów province, including Ksyel Juda Halberstam Source: DAIFO, Fond 2, desc. 1, case 2086: 96-104.

As a postscript to this story from late the 1930s of the Jewish community in Dolina and its relations with the district and provincial and national authorities, we know that Ksyel Juda Halberstam survived the Second World War, though all his family members were killed during the Holocaust. ${ }^{20}$ Ksyel Juda lived in Israel after its foundation and in 1956 he founded a settlement for the Sanz Hasidic community near Netanya, called Kiryat Sanz. There he helped establish a hospital, a children's home, schools and yeshivas. He died in 1994.

Apart from the intrigue in Dolina, we have other documents that point to the desire to control or repress. In one circular, the ministry requested that all provincial offices in Poland ensure that preliminary budgets for Jewish communities did not include expenses

\footnotetext{
18 Ibid.: 49, Report of the Examination Board.

19 DAIFO, Fond 2, desc. 1, case 2086: 96-104.

20 Personal communication from Prof. Rachel Manekin, in Kraków, 11 September 2019.
} 
for Palestinian funds, which were being sought by some Zionist organisations - implying doubts about the loyalty of these communities. ${ }^{21}$

Circulars were also sent by the Stanisławów wojewoda to all other provincial offices about candidate rabbis, informing, among other matters, that a particular candidate had failed the examination. This sharing of information between provincial offices can be seen as a further instance of the attempt to control.

Towards the end of 1938, tables on all 61 rabbis and assistant rabbis in the province were produced, containing complete biographical information on the rabbis, including on their loyalty, moral character (moralność), popularity, and proficiency in Polish. These lists were also made available to all provincial offices. ${ }^{22}$ Evidence of loyalty could also be provided by a person's activity in the mass national movements in Poland in the 1930s, such as the Maritime and Colonial League or the Air and Chemical Defence League.

At the end of the critical year of 1938, a memo marked "Urgent" went out from the ministry to all provincial offices, reminding them of the need to provide full information on all rabbis in their province. ${ }^{23}$

\section{Conclusions}

While these documents from the Ivano-Frankivsk archive (many of them strongly authoritarian in tone) may not be proof of overt antisemitism, they give the impression of suspicions on the part of the authorities regarding not only the trustworthiness of rabbis, but of the members of their congregations as well. The rabbis were not always - so the authorities suspected - sufficiently Polish, and they were increasingly obliged to prove both their proficiency in the Polish language and their loyalty to the state. There had been a rise in the activities of the Zionist movement in Poland throughout the 1920 and 1930s, particularly in towns with larger Jewish communities. Polish administrative policies aimed at controlling the clergy were, however, not unique to the rabbis - and particularly to those rabbis considered sympathizers with the Zionism movement. Such efforts of control were also directed, often vigorously, against Greek-Catholic priests in eastern Galicia, who were considered to be conducting pro-Ukrainian, anti-Polish and anti-state agitation.

Summarizing what we have found from these files from the Ivano-Frankivsk archive, we can detect during this period:

- an authoritarian urge to control, and to gather information on the rabbis;

- a statutory requirement that candidates for rabbi should be proficient at a high level in Polish;

- insistence that rabbis should be loyal to the state, and not "antinational," suggesting an underlying suspicion over their loyalty and the depth of their "Polishness."

${ }^{21}$ DAIFO, Fond 2, des. 1, case 2086: 91 Letter of the Ministry of Interior to all provincial offices regarding items in the budgets of Jewish communities relating to Palestine.

${ }^{22}$ Ibid.: 97. Urgent letter of 31 January 1938 from the Stanisławow wojewoda to the Ministry of Religious Denominations and Public Enlightenment, with tables of all the rabbis in the province attached.

${ }^{23}$ Ibid.: 107 Letter of the Ministry of Religious Denominations and Public Enlightenment of 2 December 1938 to all voivodeship offices. 


\title{
ACKNOWLEDGEMENTS
}

The authors gratefully acknowledge the valuable assistance on this article provided by Piotr Gumola.

\author{
ABBREVIATIONS \\ DAIFO - State Archive of Ivano-Frankivsk Oblast \\ DALO - The State Archives of Lviv Oblast
}

\section{BIBLIOGRAPHY}

Archival sources

Archives of Charles University, German University (Matricula doctorum and Doktoren Matrik); and Charles (Czech) University (Matrika doctoru).

Fond 187, inventories 1-6, and Fond 180, inventories 1-10.

DAIFO

Fond 2, desc. 1, case 2081, Correspondence on Religious Affairs, 1936-1937, case 2086, Correspondence on Religious Affairs, 1938.

DALO

Fond 26, desc. 10, case 1700.

\section{Printed sources}

Kronika Uniwersytetu Jana Kazimierza we Lwowie: za rok szkolny 1922-1923 (1926), Lwów.

Rozporządzenie Ministra Wyznań Religijnych i Oświecenia Publicznego z dnia 24 października 1930 r. $w$ sprawie regulaminu wyborczego dla wyborów rabinów i podrabinów w gminach wyznaniowych żydowskich na obszarze Rzeczypospolitej z wyjątkiem województwa ślaskiego [Ordinance of the Minister of Religious Denominations and Public Enlightenment of 24 October 1930, on the rules for elections of rabbis and assistant rabbis in Jewish communities in the territory of the Republic of Poland, with the exception of the Silesian voivodeship].

\section{Press}

ABC: Nowiny Codzienne 1938.

\section{Secondary sources}

Academia Militans: Uniwersytet Jana Kazimierza we Lwowie (2015), ed. A. Redzik, Kraków.

Kahane, T. (2019), Research Corner: Discoveries in the Archives, Galitzianer 26, no. 3: 10-11.

Kulczykowski, M. (2004), Żydzi - Studenci Uniwersytetu Jagiellońskiego w Drugiej Rzeczypospolitej (1918-1939), Kraków.

Mick, C. (2016), Lemberg, Lwów, L'viv, 1914-1947: Violence and Ethnicity in a Contested City, West Lafayette, IN.

Rocznik Polityczny i Gospodarczy (1939), Warszawa.

Zalewski, A. (2019), Research Corner: University Records Revisited, Galitzianer 26, no. 2: 4-9. 